\title{
The Loss of Dream, Love and Words of Women: A Brief Analysis of Three Female Characters in Winesburg, Ohio
}

\author{
Ningshuang Xiao ${ }^{1, a}$ and Hongbin Dai ${ }^{2, b,{ }^{*}}$ \\ ${ }^{1}$ Xiamen University, Xiamen, Fujian Province, China \\ ${ }^{2}$ Xiamen University, Xiamen, Fujian Province, China \\ axiaonsh@stu.xmu.edu.cn, bdhb9608@163.com \\ ${ }^{*}$ Corresponding author
}

Keywords: Winesburg, Ohio, Female characters, Loss.

\begin{abstract}
Winesburg, Ohio: A Group of Tales of Ohio Small-Town Life is a short story cycle by the American writer Sherwood Anderson. Through the eyes of the protagonist George Willard, the work presents a series of various characters living in the small town in the late $19^{\text {th }}$, each of which is of unique life experience and different personality. Among them, several female characters contribute to an inconspicuous yet important part. As gender equality is drawing more and more attention today, the analysis of female characters are more frequently carried out to help to better understand female positions in the process of social development. Therefore, this essay will focus on three representative female characters in the work, and every one of them is on behalf of one typical kind of women at that time. By analyzing their personal experiences and tragic stories, the essay presents the rough situation they are facing, what important thing they have lost in their lifetime and the reasons leading to the tragedies.
\end{abstract}

\section{Introduction}

Sherwood Anderson was a famous American writer of 20th century. Born and raised in Ohio, Anderson developed a vague but impressing childhood's memory of the hometown, which was considered to be the basis of one of his well-known works Winesburg, Ohio. With the full name as Winesburg, Ohio: A Group of Tales of Ohio Small Town Life, the book is composed of twenty-five intrinsically linked stories depicting the life of the grotesques around the male protagonist George Willard. However, in spite of that, there are about thirty-three female characters involved in these short stories, among which up to ten directly take women as the protagonists. In these chapters, Anderson portrays various female grotesques and expounds profoundly the barriers and pains they meet with, showing his sympathy and concerns to helpless women in the middle-eastern town under the situation of industrializing-America after the Civil War.

Three of the main female characters outstand in Winesburg, Ohio. They are Elizabeth Willard in the story "Mother" and "Death", Alice Hindman in the story "Adventure" and Kate Swift in the story "The Teacher". They are the spokesmen of all women there. Each of them loses one most important things in each of their life, representing three kinds of poor women at that time.

\section{Three representative female characters}

\subsection{Elizabeth Willard: the woman losing dream}

Elizabeth Willard is the mother of the male protagonist George Willard. Like most of other people, she has her own dream in her girlhood. "She dreamed of joining some company and wandering over the world, seeing always new faces and giving something out of herself to all people" (Anderson 20) [1]. However, her dream can't be understood by other people, especially men, which results in her "somewhat shaky reputation in Winesburg" (20). In men's thoughts, women should always be at home doing housework and taking care of children instead of exposing to the society. "They did not 
seem to know what she meant, or if she did get something of her passion expressed,they only laughed." (20) As time goes by, she gives up her dream and gets married, ending up with an ordinary housewife. Though she builds "a deep unexpressed bond of sympathy, based on a girlhood dream that had long ago died" between herself and her son (17), her own dream perishes.

Elizabeth deeply wants to escape from her real life, so she chooses to run one time, which can also be seen in the following two characters. As she puts it:

Thoughts came and I wanted to get away from my thoughts, I began to beat the horse. The black clouds settled down and it began to rain. I wanted to go at a terrible speed, to drive on and on forever. I wanted to get out of town, out of my clothes, out of my marriage, out of my body, out of everything. I almost killed the horse, making him run afoot into the darkness until I fell and hurt my side. I wanted to run away from everything but I wanted to run towards something too. (127)

But obviously, she can never escape from the gender discrimination of the society, which blocks off her way. A woman without dream is not able to live long. At the end of her forty-five-year's life, "the sick woman spent the last few months of her life hungering for death. Along the road of death she went, seeking, hungering." (127)

Elizabeth Willard stands for the kind of women losing their dream at that time. Everybody, man or woman, has his or her own dream, but because of the inequality in the society, women are forced to abandon theirs but help men to achieve their goals. Women can only stand behind men. No matter how hard women try to regain the dreams, they are always out of reach, which is the cruel reality of that time.

\subsection{Alice Hindman: the women losing love}

Alice Hindman is a quiet woman but "beneath a placid exterior a continual ferment went on" (59). She once has an affair with a young man named Ned Currie. When she is sixteen years old, Ned goes away to Cleveland for hoping to get a better working position. Alice is somewhat an independent girl with independent thoughts, which is worth respecting. She says, "I will work and you can work. I do not want to harness you to a needless expense that will prevent your making progress." (59) She deeply loves Ned, but the man betrays her. He marries another woman and never comes back to her.

Alice is somewhat a smart woman, for she has her own work and thinks independently, but she centers her life in Ned. From this perspective, she is a totally silly person. "For a number of years nothing could have induced her to believe that Ned Currie would not in the end return to her." (60) Even when she has earned some money, she thinks that "she would follow her lover to the city and try if her presence would not win back his affections". (60) This kind of blind love for men can be seen in all women who lose love, which becomes a deadly shortcoming of females. After reading the following passage, the image of a lonely, passionate and stubborn woman is revealed:

Alice did not blame Ned Currie for what had happened in the moonlight in the field, but felt that she could never marry another man. To her the thought of giving to another what she still felt could belong only to Ned seemed monstrous. When other young men tried to attract her attention she would have nothing to do with them. "I am his wife and shall remain his wife whether he comes back or not," she whispered to herself, and for all of her willingness to support herself could not have understood the growing modern idea of a woman's owning herself and giving and taking for her own ends in life. (60-61)

When a bowstring remains taut for a long time it might be broken; when the desire for love is repressed for a long time it needs to be released. Eventually, the instinctual desire to love and to be loved compels her to run naked out in the rainy night. She wants to be freed and to embrace another lonely man. Ironically, the man she finally finds "was an old man and somewhat deaf" (64). He is not able to comprehend her. Frightened at what she has done, she crawls home and "force herself to face bravely the fact that many people must live and die alone" (64). [2]

Alice Hindman is a typical female image falling in love. In fact, Alice Hindman has something in common with another female literature image-Megan David in John Galsworthy's The Apple Tree. Megan devotes her whole life to the love with Frank Ashurst, but the latter betrays her. Since Ashurst's departure, as an old man says in the book, "'Er never said nothin', but from that day 'er 
went kind of daze luking'; didn'seem rightly therr at all" (Galsworthy, 224) [3]. Finally, desperate and exhausted, she commits suicide in her early age. It can be seen from these two female images that women often hold the fixed opinion that they are subjected to men, and their value can only be realized when accompanied by men. However, the tighter they grab the love, the easier they will lose it. The tragedy of this kind of women is largely produced by women themselves.

\subsection{Kate Swift: the women losing words}

Kate Swift is a teacher. She is "silent, cold, and stern, and yet in an odd way very close to her pupils" (Anderson, 88), but under the cold expression is her passionate heart. Her students usually can't understand her, so she is not able to let out her enthusiastic thoughts. Therefore, she needs release. "Suddenly she sprang to her feet and, snatching a cloak from a rack by the front door, ran out of the house." (88) As readers can see, the image of running serves as a clue along these three stories, showing women's struggle to break the boundary. Kate has a listener-the male protagonist of this book, George Willard. Thinking that he will know her, Kate teaches him the principle of life. As the following paragraph shows:

The school teacher tried to bring home to the mind of the boy some conception of the difficulties he would have to face as a writer. "You will have to know life," she declared, and her voice trembled with earnestness. She took hold of George Willard's shoulders and turned him about so that she could look into his eyes. A passer-by might have thought them about to embrace. "If you are to become a writer you'll have to stop fooling with words," she explained. It would be better to give up the notion of writing until you are better prepared. Now it's time to be living. I don't want to frighten you, but I would like to make you understand the import of what you think of attempting. You must not become a mere peddler of words. The thing to learn is to know what people are thinking about, not what they say." (89-90)

Kate treats George more like a student instead of a man. She has many things to say, but she can't express herself in the man-dominated society. Therefore, she chooses her pupil. In fact, it doesn't matter to her who her listener is; she just needs a listener. She talks with passionate earnestness, hoping to open the door of life to the boy. Sadly, George's lustful thoughts for his teacher take the possession of the adolescent. [4] As a result, he misses something Kate wants to tell her. Though struggling hard, Kate has to face the helpless reality that woman's voice can't be heard. She loses her word. That's why most women at that time were silent to death.

\section{Summary}

The above-mentioned three women are just representatives of late $19^{\text {th }}$ century American females. At that time, women are "invisible" in society, "because their real identities are eclipsed by their social roles" (qtd. in Rigsbee 233) ${ }^{1}$. The setbacks, frustration, and failure that encompass the lives of Elizabeth Willard, Alice Hindman and Kate Swift result from the discrepancy between their own capacity for creativity and the inability of men in their lives. By depicting these female characters, Anderson inspires people to have a deep thought on women's living situation and advocates gender equity, which is advanced and humanistic[5].

\section{References}

[1] Anderson. Sherwood, Winesburg, Ohio, New York: W. W. Norton \& Company, Inc, pp. 20, 1996. Page numbers of the following quotes from this novel will be included in the parenthesis.

1 From Studies in American Fiction 9 (Fall 1981): 233-44. Reprinted by permission of Studies in American Fiction and Northeastern University. Page references in brackets are to this Norton Critical Edition. 
[2] L. Dou, A Brief Analysis on Main Characters of Two Short Stories_- "Hands" and "Adventure" in Winesburg, Ohio from Freud's Tripartite Personality Structure Theory, Overseas English, vol.11, pp. 189-190, 2014.

[3] G. John, The Apple Tree, Trans. Liu Lijun, Beijing: China Astronautic Publishing House, pp.224, 2011.

[4] W. Weiping, The Female Images in Winesburg, Ohio, Journal of Hubei University of Economics(Humanities and Social Sciences), vol. 7, pp. 119-121, 2010.

[5] X. Jing and L. Xiaolan, On the Female Grotesques in Winesburg, Ohio, Science and Technology Information, vol. 5, pp. 260, 2012. 